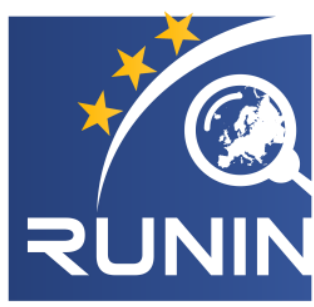

The Role of Universities in Innovation and Regional Development

\title{
The Integration of Collaboration SkIlls in Doctoral Education
}

WORKING PAPER 13/2018

DOI: $10.3990 / 4.2535-5686.2018 .13$

Available at https://runinproject.eu/results/working-paper-series/

\section{Eloïse Germaln-Alamartine}

Department of Management and Engineering - Linköping University eloise.germain@liu.se 


\section{Abstract}

As for all sorts of education programs, the first aim in doctoral education is to educate students with the skills they need in their professional life, as researchers in this case. Career opportunities for doctoral graduates can be found, obviously, in academia, but also outside it as employed by a non-academic organisation or as self-employed. For each of these career possibilities, collaboration is crucial. However, collaboration skills are not systematically integrated in doctoral education curricula, or at least not explicitly. Doctoral education thus calls for a reform to integrate the teaching of such skills; and this reform can happen only through the definition of collaboration skills and through the implementation of different kinds of collaboration opportunities.

Keywords: doctoral education, PhD, skills, collaboration

JEL: I23, J24

This paper version was written in the framework of the PhD course "Collaboration as a researcher. Reflection and practice on usefulness and relevance" held at Linköping University between September 2017 and June 2018. It was presented during the last seminar of the course in June 2018. 


\section{Table of Contents}

The Integration of Collaboration Skills in Doctoral Education ......................................1

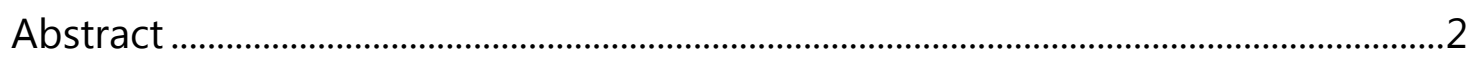

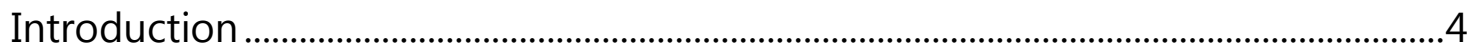

The hard task of defining collaboration skills..................................................................

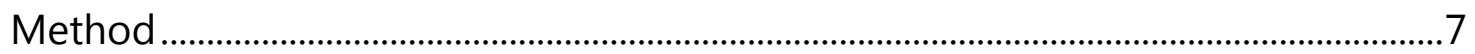

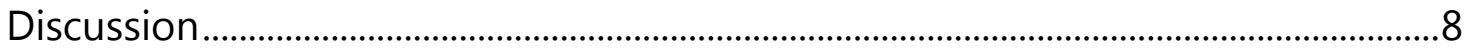

Doctoral education for both academic and non-academic careers ......................8

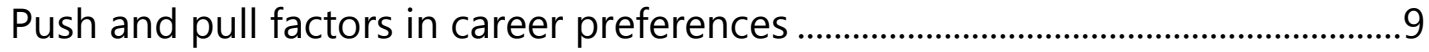

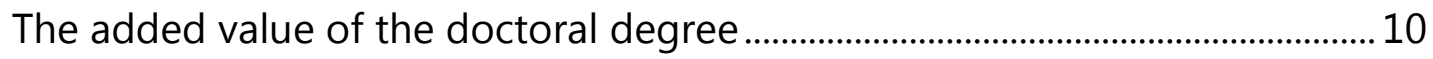

Transitioning from academia to the non-academic labour market.................... 12

The need for a reform of doctoral education................................................................. 15

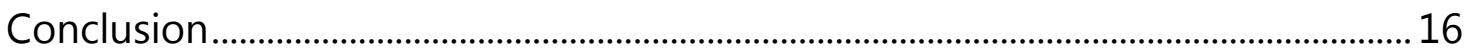

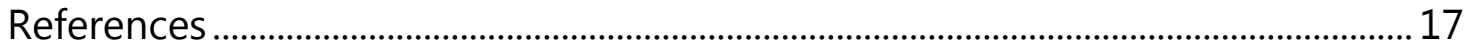

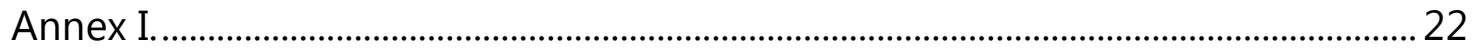




\section{Introduction}

The roles of universities and careers in academia are evolving and require a reform of doctoral education. Moreover, even though the doctoral degree was designed for an academic career in the first place, there is an increasingly important labour market for doctorate holders outside academia. Universities are the only suppliers of doctoral education and as such the only suppliers of doctoral workforce to the non-academic labour market. Understanding the needs of non-academic employers is thus crucial for universities to adapt their doctoral education offer. It is all the more important as skills' mismatches are observed and are expected to grow in the near future.

This essay aims at exploring the integration of collaboration skills in doctoral education. It uses theoretical and empirical studies to support it. The following question guides it: why are collaboration skills relevant for doctoral students and worth being integrated in doctoral education?

After discussing what collaboration skills are, the method used for this essay will be described. The discussion on the relevance of collaboration skills in doctoral education will follow, with a conclusion emphasizing the need to further collaboration in this area. 


\section{The hard task of defining collaboration skills}

Collaboration skills are very varied. Collaboration itself is hard to define since it covers many aspects of a work or action conducted with one other stakeholder or more. Collaboration, cooperation, and engagement are terms used intensively and interchangeably in the literature dealing with inter-organisational relations. Some researchers use different terms that consider the degree of involvement of stakeholders influencing the research methodology. For instance, interactive research (Ellström et al., 1999) implies an iterative collaborative process to make sure the research is as close to the practice as possible, with attempts to keep a certain distance to avoid too much bias. Action research (Brydon-Miller et al., 2003) on the other hand places the researcher at the heart of the studied phenomenon, in which (s)he takes part; this methodology has been vividly criticized because it might bring too much subjectivity into the research work. Other researchers focus on the concrete ways in which collaboration occurs: for example, the 'academic engagement' defined by Perkmann et al. (2013) "is varied and includes collaborative research, contract research, consulting and other forms of knowledge exchange" (p. 425). Instead of focusing on the methodology, others focus on the conceptual understanding of research engagement. Fransman (2018) proposes a holistic framework, drawing from the literature on different domains of policy and practice, represented in the form of a cube (cf. Annex I, Figure 2): research engagement can be defined in terms of locus, analytical lens and configuration. This holistic approach really shows the complexity and all the nuances implied in engagement, or collaboration.

In the literature on doctoral education, collaboration skills seem to be part of what are called transversal, generic or transferable skills: those skills that are not the scientific skills that make the doctoral graduate an expert in his/her field. Some of these transversal skills are already present in doctoral education requirements: for instance, in Sweden, doctoral students should be able to "demonstrate the ability in both national and international contexts to present and discuss research and research findings authoritatively in speech and writing and in dialogue with the academic community and society in general" (translated from Examensmål för licentiat - och doktorsexamen enligt Högskoleförordningen (1993:100, bilaga 2)).

However, there is no consensus on their definition and denomination. Some researchers have made complete lists of skills that are expected from doctorate 


\section{The Integration of Collaboration Skills in Doctoral Education}

holders. They have done so through policy recommendations that are a basis for the standardisation of doctoral education - or Europeanisation of doctoral training (Djelic, 2008). In 2012, the OECD published a report focusing on policies implemented in some OECD countries to train researchers with transferable skills. The main results are that trainings are very heterogeneous between countries and even within a country (OECD, 2012). Also, "there appears to be no consensus regarding which transferable skills are most needed at different career stages" (OECD, 2012, p.34). In spite that, the League of European Research Universities, arguing in 2016 that "it is talent more than technology that society or business needs from universities" (LERU, 2016, p.2), made a clear list of 25 skills for PhD graduates, as well as justifications and recommendations to develop them. The list is divided into 3 categories: intellectual skills, academic and technical skills and personal and professional management skills. The Careers Research and Advisory Centre, in the UK, presents an even more complete set of skills to develop for a researcher, and phases of development for each skill: 63 skills that are divided into 4 domains, where we find again intellectual abilities, personal effectiveness, professional conduct and where engagement and impact can also be found (Vitae, 2011). This Vitae framework has been used as a reference for developing Universitat Autònoma de Barcelona's Professional Competencies Framework, for instance (UAB, 2017).

Considering these various classifications as sources of inspiration, collaboration skills are defined in this essay as all the skills needed in conducting collaborative research, from the first to the last contact with the partners of the collaboration. It includes for instance communication skills, negotiation skills, research management skills, intellectual property skills, as well as other more specific methodological skills, such as action research skills. 


\section{Method}

This paper is based on a review of the scientific literature and policy documents on doctoral education, the careers of doctorate holders, skills' mismatches, transferable skills and university-industry collaboration. It also uses articles in development by the author:

- An article consisting in descriptive statistics on the integration of doctorate holders' in a regional labour market and the satisfaction of regional employers. The article aims at formulating hypotheses on the characteristics of the regional labour market, in particular on the existing link between the choice of doctorate holders to stay in the region and the mismatched employment situation that can be observed in many cases (GermainAlamartine, 2018, in review);

- An article consisting in a comparative case study of two Research and Science Parks (one in Sweden, one in Spain) regarding the needs for doctoral skills in the Science Parks, based on a series of interviews analysed using the Gioia methodology (Germain-Alamartine \& Moghadam-Saman, 2018, work in progress).

Finally, some reflections also come from a think-tank organized at the University of Twente in June 2018, where I was a table host on the question "How far should society influence the University of Twente in its teaching and research activities" (RUNIN, 2018). 


\section{Discussion}

\section{Doctoral education for both academic and non-academic careers}

Doctoral education needs to be adapted to both evolving academic and nonacademic careers. The roles of universities and careers in academia are evolving and require a reform of doctoral education. University-industry collaboration is increasingly frequent and some researchers' careers are no longer purely academic, but "hybrid", navigating between academia and industry.

Even though the doctoral degree was designed for an academic career in the first place, there is an increasingly important labour market for doctorate holders outside academia. Statistics on the doctorate holders' labour market as a whole at national and trans-national scales show that there is an increasing demand for doctorate holders in non-academic organisations (Auriol et al., 2013; Neumann \& Tan, 2011; Garcia-Quevedo et al., 2012). Using a collection of data from OECD countries, Auriol et al. (2013) observe that "although the higher education sector is the main sector of employment for doctorates, demand for doctorates is apparent across other sectors of the economy" (Ariol et al., p.6).

This trend of increasing doctoral workforce, sometimes referred to as 'too many PhD graduates' (Larson et al., 2014), can be observed in countries where innovation and research systems are well developed, but not where these systems are being developed such as Portugal (Santos et al., 2016). Etmanski et al. (2017) assess that less than $15 \%$ of PhD graduates get a professorship in Canada, while in Australia, "only one-quarter of all doctoral graduates are initially employed in academic positions on completion of their PhD' (Neumann \& Tan, 2011, p.609). A determining characteristic of the academic labour market is the bottleneck in the availability of academic positions, which makes the postdoctoral workforce form a queue waiting for tenure-track positions (Andalib et al., 2018).

Universities are the only suppliers of doctoral education and as such the only suppliers of doctoral workforce to the non-academic labour market. Understanding the needs of non-academic employers is thus crucial for universities to adapt their doctoral education offer. Nyquist (2002) calls for a revision of the doctoral education in the United States, highlighting the fact that the skills expected from doctorate holders have considerably evolved due to an increased employment in non-academic sectors as well as increased expectations from 


\section{The Integration of Collaboration Skills in Doctoral Education}

society. Thune et al. (2012), suggest among the three criteria to assess the quality of a doctoral education system, insisting on the relevance of doctoral education throughout the country.

It is crucial as skills' mismatches are observed and are expected to grow in the near future. The European Centre for the Development of Vocational Training (Cedefop, 2016) predicts that progressively more highly educated workforce will work in jobs requiring a lower level of education, to reach $14 \%$ of the employed population in Europe in 2025. To make up for this skills' mismatch, employers tend to favour a higher level of experience (Kulkarni et al., 2015). This mismatch has consequences on the employment situation of doctorate holders, especially on wages (Gaeta et al., 2016; Allen \& Van der Velden, 2001).

\section{Push and pull factors in career preferences}

The increasing importance of the non-academic labour market for doctorate holders is also due to graduates' career preferences. Bloch et al. (2015) distinguish 'pull factors' - such as individual preferences - and 'push factors' - such as the supply of PhDs and the availability of jobs - that influence the choice of working inside or outside academia. Push factors are from the demand side of the labour market, for example the availability of jobs, in or outside academia, as evoked earlier. Pull factors are from the supply side of the labour market. They can be individual preferences of doctorate holders for employment, in form (e.g. type of contract) or in content (e.g. job responsibilities). Many authors focus on these pull factors (Roach \& Sauermann, 2010; Sauermann \& Roach, 2012; Cruz-Castro \& Sanz-Menendez, 2005). Roach \& Sauermann (2017) for instance find that many $\mathrm{PhD}$ students realize during their doctoral training that they do not want to work in academia; but this change of mind is not mainly related to the lack of job opportunities. As an interviewee from Catalonia stated when asked why she chose to switch from working in academia to working in a private company (extracted from the data collected for Germain-Alamartine \& Moghadam-Saman, 2018, work in progress):

"Stability. (...) When you are at the university and you do your PhD, they usually take you to one or two postdocs after the PhD, and the goal is to become a PI (Principal Investigador) and have your own lab. But that was never my goal, ever. My husband he's a PI so I know how stressful it is, and what kind of life you have, and your life, it's all the 


\section{The Integration of Collaboration Skills in Doctoral Education}

time in a question mark. If you don't get the grant, you will have to close the lab. So you are in a huge stress all the time, writing grants, and then being lucky to get one grant so you can continue your research. So even though for my personality I never wanted to be the PI having a lab, after I did my PhD it was clear for me that I didn't want it to have my own lab. And so the two works after my PhD there were no postdocs, it was more like lab manager or like senior researcher helping other PhDs but they were not considered a postdoc job. And of course, when you finish your PhD you get to a point of life when you want some stability, you want to form a family for example, or you want to be able to buy a house, and with research in university it's impossible to know that. So you work in a grant that will finish in two years, after those two years if your PI doesn't have another grant then you are out, so you have the feeling like the same feeling when you finish your degree at the university that and now what? You have that feeling constantly, every two years you have that feeling, and that was not compatible with my way, what I wanted in my personal life to have a family and kind of settle in a place. That's why I switched."

Pull factors can also be derived from characteristics of doctoral education, such as the type of funding of the thesis (Mangematin, 2000), the number of publications (Mangematin et al., 2000), or a support for academic entrepreneurship, mobility and collaboration with the private sector (Bienkowska et al., 2016).

\section{The added value of the doctoral degree}

For doctoral graduates choosing to pursue a non-academic career, a problem is that the doctoral degree does not seem to present any practical added value in the eyes of most non-academic employers. Of course, there are many employers that hire doctoral workforce at the level of its worth: Garcia-Quevedo et al. (2012) find out that the $\mathrm{PhD}$ is estimated by employers in industry as highly valuable; but in practice, only firms having intense R\&D really hire PhD holders. According to Herrera and Nieto (2013), companies need such workforce to access scientific knowledge, to solve previous failures in innovation activities and to find innovation partners and external R\&D funding more easily.

However, in Catalonia, descriptive statistics on a 2017 survey of doctorate holders and a 2014 survey of employers seem to show that a lot of non-academic regional employers do not grasp the added value of the doctoral degree compared with 


\section{The Integration of Collaboration Skills in Doctoral Education}

other higher education degrees (Germain-Alamartine, 2018, in review): "The valorisation of the doctoral degree by regional employers seems marginal compared to other university degrees but is nevertheless existing. $10 \%$ of the sample of employers valorize [sic] the doctoral degree as important in the recruitment process, while 34\% valorize [sic] the master degree instead' (p. 13). Differences are also observed between doctoral graduates who declare having needed their doctoral degree in the recruitment process, and those who declare not having needed it.

Interviews with employers of a Research Park - the majority of whom are themselves doctorate holders - indicate that the main added value of the doctoral degree is the prestigious image it implies, for academic excellence and scientific expertise (extracted from the data collected for Germain-Alamartine \& Moghadam-Saman, 2018, work in progress):

"A doctor has an added value: imagine a situation in which I have a company and that company is at least more important than a start-up because a start-up has nothing, has no name, has no market, has nothing. But imagine that I have a company and that company has a brand or a name or a reputation or something like that in the market and I want to develop something and I want to differentiate me and my competitors. Maybe it's important for me to have doctors, and to say 'I have a team, a very strong team, look what they can do in my team, there is a doctor, or professor."

\section{"[...] somehow having a PhD in a sense is like a certification you know, that you have that kind of experience, that you had to deal in this kind of ability to manage a problem so in this sense it's an added value."}

Transferable skills, including collaboration skills, are very important because they are usable both in research-intensive and non-research-intensive careers and they can be an added value in the eyes of non-academic employers. Since there is a widening of the range of career prospects for doctoral graduates, the acquisition of skills that go beyond the core research skills and beyond specialised skills is gaining more attention and importance. Such skills are called transferable, transversal or generic. The majority of transferable skills are usable across both research-intensive and non-research-intensive careers (Sinche et al., 2017). Kyvik 


\section{The Integration of Collaboration Skills in Doctoral Education}

and Olsen (2012) observed that generic skills obtained during the doctoral period are most valued for those who find employment outside the research system.

Durette et al. (2014) focus on core competencies of doctoral students and doctorate holders in France, that they define as "competencies that have the same probability of being developed through the PhD irrespectively of the discipline, the date of graduation and other factors" (Durette et al., 2014, p.4). They found that only $1 / 4$ of the competencies evoked by respondents correspond to core competencies. From their qualitative analysis, they developed a typology of skills with 6 categories: specialised skills, transferable skills that can be formalised, transferable skills that cannot be formalised, dispositions, behaviours and metacompetencies (cf. Durette et al., 2014, pp.29-33). Since core competencies are the outcome of doctoral education, they seem to also be the added value of doctoral education.

Interviews with employers from a Research and Science Park mainly look for generic skills (extracted from the data collected for Germain-Alamartine \& Moghadam-Saman, 2018, work in progress):

"I'm looking for an attitude";

"In terms of transversal skills, for us, of course it's important the technical skills but also the ability to communicate [...]; also the ability to work in groups, which is important because sometimes the projects must be carried out on their own but sometimes there is a teamwork on projects; [...] yes, more or less these are the skills that are important for us."

\section{Transitioning from academia to the non-academic labour market}

Collaboration experiences during the $\mathrm{PhD}$ facilitates the access to a non-academic career after the doctoral graduation. Mangematin (2000) finds that for PhD holders looking for their first jobs, "switching from academia to the private sector or vice versa depends on whether or not they collaborated with the private sector during their PhD and on the intensity of publication" (Mangematin, 2000, p.1). Fritsch \& Krabel (2012) find that having previously worked in or with the private sector seems to have a positive impact on the choice of working in the private sector. This was also expressed by an employer in an interview (extracted from the data collected for Germain-Alamartine \& Moghadam-Saman, 2018, work in progress): 


\section{The Integration of Collaboration Skills in Doctoral Education}

"At the moment the majority of people that we have are not PhD students. They finished their PhD, so they're postdocs, and what they work on our projects, so for [major company name] so they're all what you consider industrial kind of postdoc and when they come here it's a kind of stepping stone because we're still part of academia and we're part of a company. So good place if the postdoc doesn't know yet if they want to stay in academia or does he want to join a company, a good stepping stone to come in and to decide one way or the other is to get a position here."

Collaboration skills are also necessary for doctoral graduates who choose a selfemployed career. Sauermann \& Roach (2012) observe that PhD students tend to be less and less attracted by the perspective of pursuing an academic career over the time of their PhD studies, even if supervisors attempt to influence these career preferences towards academia.

Other studies showed that entrepreneurship are possible solutions for doctorate holders to find a better suited employment, thus reducing the labour market mismatch (Stenard \& Sauermann, 2016). A doctoral graduate who chose to become a self-employed entrepreneur explains how collaboration with a Research Park and with his former university are important for his activities (extracted from the data collected for Germain-Alamartine \& Moghadam-Saman, 2018, work in progress):

"(...) We were PhD students as I said, so we had no clue how to set up a company, which were the steps, how to make a business plan. We were academics, not entrepreneurs, so they helped us to do these first steps and mainly to do the business plan. We had support from them to do the business plan and we had some follow-ups. (...)

Q: And was it difficult to keep the links with the university?

No, not difficult because as we've been working for free for many years (laughing) they were very keen on having us there but it was just a matter of putting some time. But the relationship was more enthusiastic from our side to be there, to teach for free, as I say, or to supervise master thesis or PhD thesis for free. But what we obtained was a place to test new methodologies, for instance. In our field there's new methodologies, they're water footprint so we were selling 


\section{The Integration of Collaboration Skills in Doctoral Education}

consultancy on carbon footprint but water footprint was being developed, and was not ready to the market so we made some master theses on water footprint. So that gave us the opportunity to test this methodology, to learn about the methodology before selling it and now we are marketing this. So, yes it's like a lab for us, a place to test methodologies or ideas, it's also nice to have this."

For doctoral graduates choosing to pursue an academic career, collaboration skills are relevant since collaboration is increasingly expected in academic careers and represents a great part of research evaluation systems nowadays. Kuhlmann (2003) evokes the summative function of evaluation processes, corresponding to the measurement of performance that provides legitimacy for promotional measures. In terms of academic career, thus, evaluation processes are crucial for researchers and since doctoral education is designed to train doctoral students to become researchers, knowing about evaluation systems and how to deal with them is necessary. At Linköping University for example, one of the requirements to get promoted from Associate Professor to Professor is formulated as follow: "An associate professor with a permanent position at the university may, following application, be subject to an assessment of qualifications and be promoted to a permanent position as professor if he or she: (...) has shown the ability to plan, organise and carry out positive collaboration in an educational setting, with the purpose of ensuring the relevance of the education for professional employment, and in preparation for such employment" (LiU, 2018). In addition, working in academia also means being able to get funding to conduct research. In Sweden, cooperation is a requirement to get funding from Vinnova (Vinnova, 2018). 


\section{The need for a reform of doctoral education}

In both academic and non-academic career prospects, a reform of doctoral education is needed to integrate more collaboration skills, but collaboration is also needed to conduct the reform efficiently. Indeed, despite an obvious necessity of collaboration skills for doctoral students, collaboration skills are not evoked at all in the list of expected skills to be mastered by a doctoral graduate in Sweden (Examensmål för licentiat- och doktorsexamen enligt Högskoleförordningen (1993:100, bilaga 2)). Recognising the necessity to adapt the doctoral training, new forms of doing a PhD have emerged in some countries. Benito and Romera (2013) highlight the recent developments and new models in $\mathrm{PhD}$ training which link university and industry more systemically, such as the professional doctorate introduced in the UK, The Netherlands and Austria. They also emphasise the importance of a good level of effective collaboration between institutions to boost the PhD labour market. This is in line with Boud and Tennant's (2006) earlier conclusion regarding the role of cultural practices of academic institutions (besides the rules and regulations and doctoral program details) to meet contemporary needs in PhD education for 'relevance'. A reform of doctoral education, sometimes conducted in collaboration with the private sector, has already begun (Metcalfe, 2006).

Roberts's (2018) systematic literature review qualifies industry involvement in PhD education as 'best practice' (p. 7), in line with Assbring \& Nuur's (2017) concept of collaborative doctoral education. In some countries, practice-oriented doctoral programs, called industrial or professional $\mathrm{PhDs}$, have been implemented, most of the time in the form of university-industry collaboration. In France, CIFRE theses are a national initiative that has been working since 1981 (CIFRE means 'convention industrielle de formation par la recherche', that can be translated as industrial agreement of training by research) (MESRI, 2018). In Spain, doctorats industrials (industrial $\mathrm{PhDs}$ ) are a regional initiative from the Catalan government that was recently launched (in the 2010s) (GENCAT, 2018). 


\section{Conclusion}

This essay argues for the necessity of collaboration skills in doctoral education, summarized in figure 1.

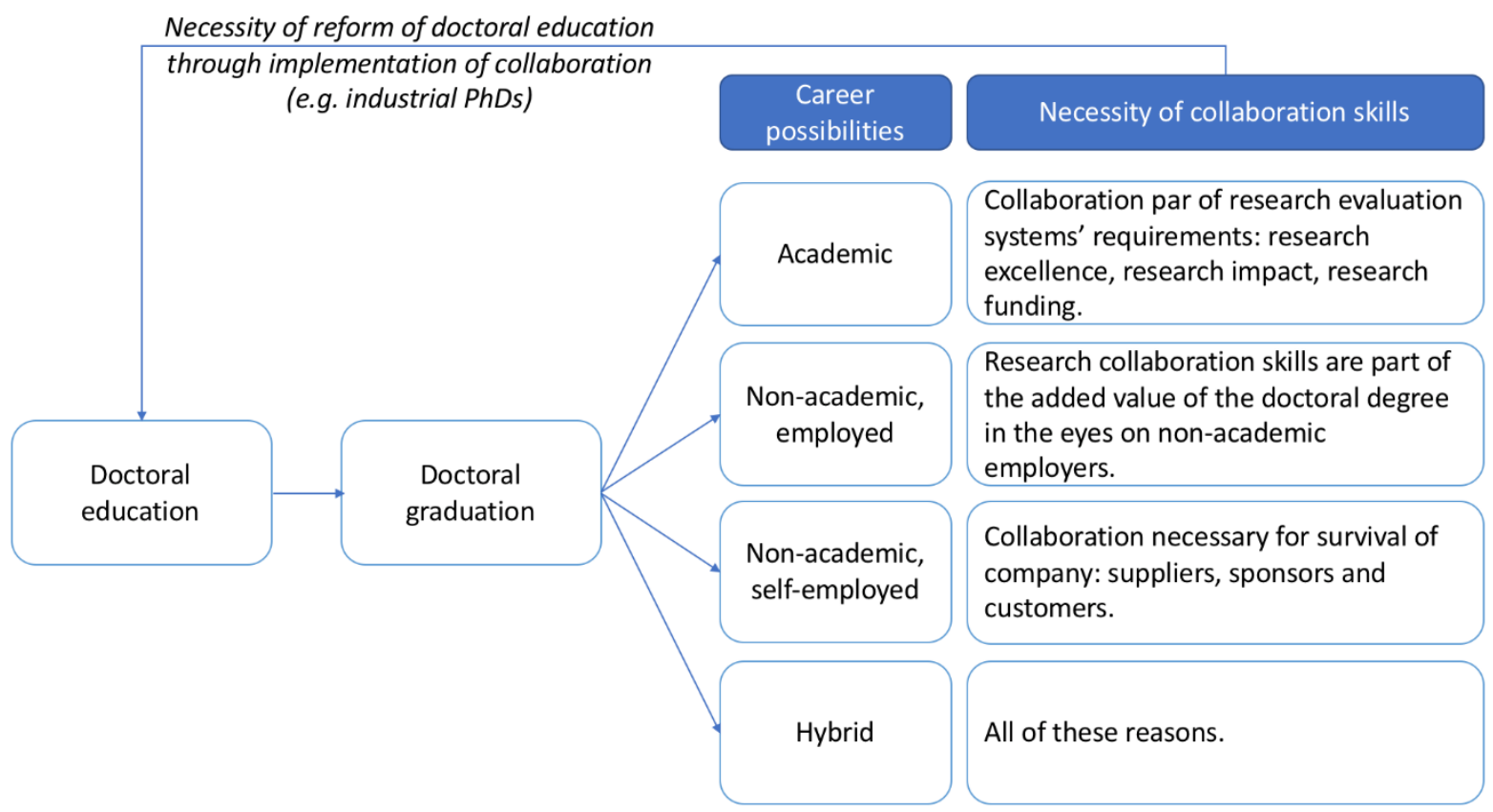

Figure 1: The necessity of collaboration skills in doctoral education.

All types of collaboration skills are relevant for doctoral students. There are so many things to learn that it is not necessarily possible to learn everything in three years. The doctoral student should make choices and prioritise in function of his needs and interests. In addition, in practice, the university cannot teach all collaboration skills to doctoral students: there are a variety of ways to acquire such skills. Such skills can be acquired by: self-education; the supervision process; an involvement in networks; formal courses; or, implicitly, through the culture of the university's department.

But the university should open opportunities for them to develop these skills. This is part of its responsibility to provide an education that leads to employability thus making the doctoral degree an added value on the labour market. 


\section{References}

Allen, J., \& Van der Velden, R. (2001). Educational mismatches versus skill mismatches: effects on wages, job satisfaction, and on-the-job search. Oxford economic papers, 53(3), 434-452.

Andalib, M. A., Ghaffarzadegan, N., \& Larson, R. C. (2016). The Postdoc Queue: A Labour Force in Waiting. Systems Research and Behavioral Science.

Arnstein, Sherry R.(1969) 'A Ladder Of Citizen Participation', Journal of the American Planning Association, 35: 4, 216 - 224

Assbring, L., \& Nuur, C. (2017). What's in it for industry? A case study on collaborative doctoral education in Sweden. Industry and Higher Education, 31(3), 184-194.

Auriol, L., Misu, M., \& Freeman, R. A. (2013). Careers of doctorate holders.

Benito, M., \& Romera, R. (2013). How to boost the PHD labour market?: facts from the PHD system side.

Bienkowska, D., Klofsten, M., \& Rasmussen, E. (2016). PhD Students in the Entrepreneurial University-Perceived Support for Academic Entrepreneurship. European Journal of Education, 51(1), 56-72.

Bloch, C., Graversen, E. K., \& Pedersen, H. S. (2015). Researcher mobility and sector career choices among doctorate holders. Research Evaluation, 24(2), 171-180.

Boud, D., \& Tennant, M. (2006). Putting doctoral education to work: challenges to academic practice. Higher Education Research \& Development, 25(3), 293-306.

Brydon-Miller, M., Greenwood, D. and Maguire, P. (2003). Why Action Research?, Action Research, 1(1), 9-28.

Cedefop (2016). Future skill needs in Europe: critical labour force trends. Luxembourg: Publications Office. Cedefop research paper; No 59.

Cruz-Castro, L., \& Sanz-Menéndez, L. (2005). The employment of PhDs in firms: trajectories, mobility and innovation. Research evaluation, 14(1), 57-69.

Djelic, M. L. (2008). PhD education-Challenges and opportunities of Europeanization. European universities in transition, 49-68. 
Durette, B., Fournier, M., \& Lafon, M. (2016). The core competencies of PhDs. Studies in Higher Education, 41(8), 1355-1370.

Ellström, P-E., Eklund, J., Kock, H., Lindström, L., Melin, U. (1999). Knowledge Creation Through Collaborative Research: An Emerging Model, presenterat vid konferensen Högskolor och Samhälle i Samverkan (HSS'99), 16-18 mars, Falun (CMTO Research Paper Series).

Etmanski, B., Walters, D., \& Zarifa, D. (2017). Not What I Expected: Early Career Prospects of Doctoral Graduates in Academia. Canadian Journal of Higher Education, 47(3), 152-169.

Fransman, F. (2018) Charting a course to an emerging field of 'research engagement studies': A conceptual meta-synthesis, forthcoming in Research for All. Available at: https://www.ingentaconnect.com/contentone/ioep/rfa/2018/00000002/0000 0002/art00002?crawler =true\&mimetype = application/pdf

Fritsch, M., \& Krabel, S. (2012). Ready to leave the ivory tower?: Academic scientists' appeal to work in the private sector. The Journal of Technology Transfer, 37(3), 271-296.

Gaeta, G. L., Lubrano Lavadera, G., \& Pastore, F. (2016). Much ado about nothing? the wage effect of holding a ph. $d$. degree but not a ph. d. job position.

Garcia-Quevedo, J., Mas-Verdú, F., \& Polo-Otero, J. (2012). Which firms want PhDs? An analysis of the determinants of the demand. Higher Education, 63(5), 607620.

GENCAT. (2018). Doctorats industrials. Retrieved from: http://doctoratsindustrials.gencat.cat/ca

Germain-Alamartine, E. (2018, in review). Doctoral education and employment in the region: the case of Catalonia.

Germain-Alamartine, E. \& Moghadam-Saman, S. (2018, work in progress). Providing doctoral skills to the regional labour market: Cases of University relations with Science Parks. 


\section{The Integration of Collaboration Skills in Doctoral Education}

Herrera, L., \& Nieto, M. (2013). Recruitment of PhD researchers by firms. In 35th DRUID Celebration Conference, Barcelona, Spain. Google Scholar.

Kuhlmann, S. (2003): Evaluation as a source of 'strategic intelligence'. In: Shapira, Ph., Kuhlmann, S. (eds.): Learning from Science and Technology Policy Evaluation: Experiences from the United States and Europe, Cheltenham (E. Elgar), 352-379.

Kulkarni, M., Lengnick-Hall, M. L., \& Martinez, P. G. (2015). Overqualification, mismatched qualification, and hiring decisions: Perceptions of employers. Personnel Review, 44(4), 529-549.

Kyvik, S., \& Olsen, T. B. (2012). The relevance of doctoral training in different labour markets. Journal of Education and Work, 25(2), 205-224.

Larson, R. C., Ghaffarzadegan, N., \& Xue, Y. (2014). Too many PhD graduates or too few academic job openings: the basic reproductive number R0 in academia. Systems research and behavioral science, 31(6), 745-750.

LERU (2016). Maintaining a quality culture in doctoral education: At researchintensive universities. https://www.leru.org/publications/maintaining-aquality-culture-in-doctoral-education-at-research-intensive-universities\#

Linköping University. (2018). Promotion from Assistant Professor to Professor. Retrieved from: https://old.liu.se/insidan/HR-Personal/befordran-ochdocent/befordran/professor?|=en

Mangematin, V. (2000). PhD job market: professional trajectories and incentives during the PhD. Research policy, 29(6), 741-756.

Mangematin, V., Mandran, N., \& Crozet, A. (2000). The careers of social science doctoral graduates in France: the influence of how the research was carried out. European Journal of Education, 35(1), 111-124.

MESRI. (2018). Conventions industrielles de formation par la recherche (CIFRE). Retrieved from: http://www.enseignementsuprecherche.gouv.fr/cid22130/les-cifre.html

Metcalfe, J. (2006). The changing nature of doctoral programmes. Wenner Gren International Series, 83, 79. 


\section{The Integration of Collaboration Skills in Doctoral Education}

Neumann, R., \& Tan, K. K. (2011). From PhD to initial employment: the doctorate in a knowledge economy. Studies in Higher Education, 36(5), 601-614.

Nyquist, J. D. (2002). The PhD a tapestry of change for the 21st Century. Change: The Magazine of Higher Learning, 34(6), 12-20.

OECD (2012). Transferable Skills Training for Researchers: Supporting Career Development and Research. OECD Publishing.

Perkmann, M., Tartari, V., McKelvey, M., Autio, E., Broström, A., D’Este, P., ... Sobrero, M. (2013). Academic engagement and commercialisation: A review of the literature on university-industry relations. Research Policy, 42(2), 423-442.

REF. (2018). What is the REF? Retrieved from: http://www.ref.ac.uk/about/whatref/

Roach, M., \& Sauermann, H. (2010). A taste for science? PhD scientists' academic orientation and self-selection into research careers in industry. Research Policy, 39(3), 422-434.

Roach M, Sauermann H (2017) The declining interest in an academic career. PLoS ONE 12(9): e0184130.

Roberts, A. G. (2018). Industry and PhD engagement programs: inspiring collaboration and driving knowledge exchange. Perspectives: Policy and Practice in Higher Education, 1-9.

RUNIN (2018). Reconnecting the University to the Region of Twente. Available at: https://www.researchgate.net/publication/328202519_Reconnecting_the_Univ ersity_to_the_Region_of_Twente_Findings_from_the_RUNIN-

Design_Lab_Think_Tank?_sg=dyXdBuDzhOu8DQtfPS6IwYKuKUpyfuv7VFkGnY V6EvzUBxTTsWqpo4wRWYMTAvhiOeDtBWMNVSGIaA.uBR_LBt3XDDZe1_thd 04ew7cjTx4nIn5umXJzz5uQK94tZ4mabS9g8_vqGnoB5BrgOzPJZasUWnzDfQc n3s5Og\&_sgd\%5Bnc\%5D=11\&_sgd\%5Bncwor\%5D=0

Santos, J. M., Horta, H., \& Heitor, M. (2016). Too many PhDs? An invalid argument for countries developing their scientific and academic systems: The case of Portugal. Technological Forecasting and Social Change, 113, 352-362.

Sauermann, H., \& Roach, M. (2012). Science PhD career preferences: levels, changes, and advisor encouragement. PloS one, 7(5), e36307. 


\section{The Integration of Collaboration Skills in Doctoral Education}

Sinche, M., Layton, R. L., Brandt, P. D., O'Connell, A. B., Hall, J. D., Freeman, A. M., ... \& Brennwald, P. J. (2017). An evidence-based evaluation of transferrable skills and job satisfaction for science PhDs. PloS one, 12(9), e0185023.

Stenard, B. S., \& Sauermann, H. (2016). Educational mismatch, work outcomes, and entry into entrepreneurship. Organization Science, 27(4), 801-824.

Thune, T., Kyvik, S., Sörlin, S., Olsen, T. B., Vabø, A., \& Tømte, C. (2012). PhD education in a knowledge society: An evaluation of PhD education in Norway.

UAB (2017). UAB Professional Competencies Framework. http://www.uab.cat/web/research/itineraries/uab-research/euraxessuab/uab-professional-competencies-framework-1345704297585.html

Vinnova. (2018). How to apply for funding? Retrieved from: https://www.vinnova.se/en/apply-for-funding/how-to-apply-for-funding/

Vitae (2011). Vitae Researcher Development Framework (RDF) 2011. https://www.vitae.ac.uk/vitae-publications/rdf-related/researcherdevelopment-framework-rdf-vitae.pdf 


\section{The Integration of Collaboration Skills in Doctoral Education}

\section{Annex I.}

Figure 2 - Understanding research engagement: a Rubix Cube of the emerging field of research engagement studies. Source: Fransman (2018), p. 208.

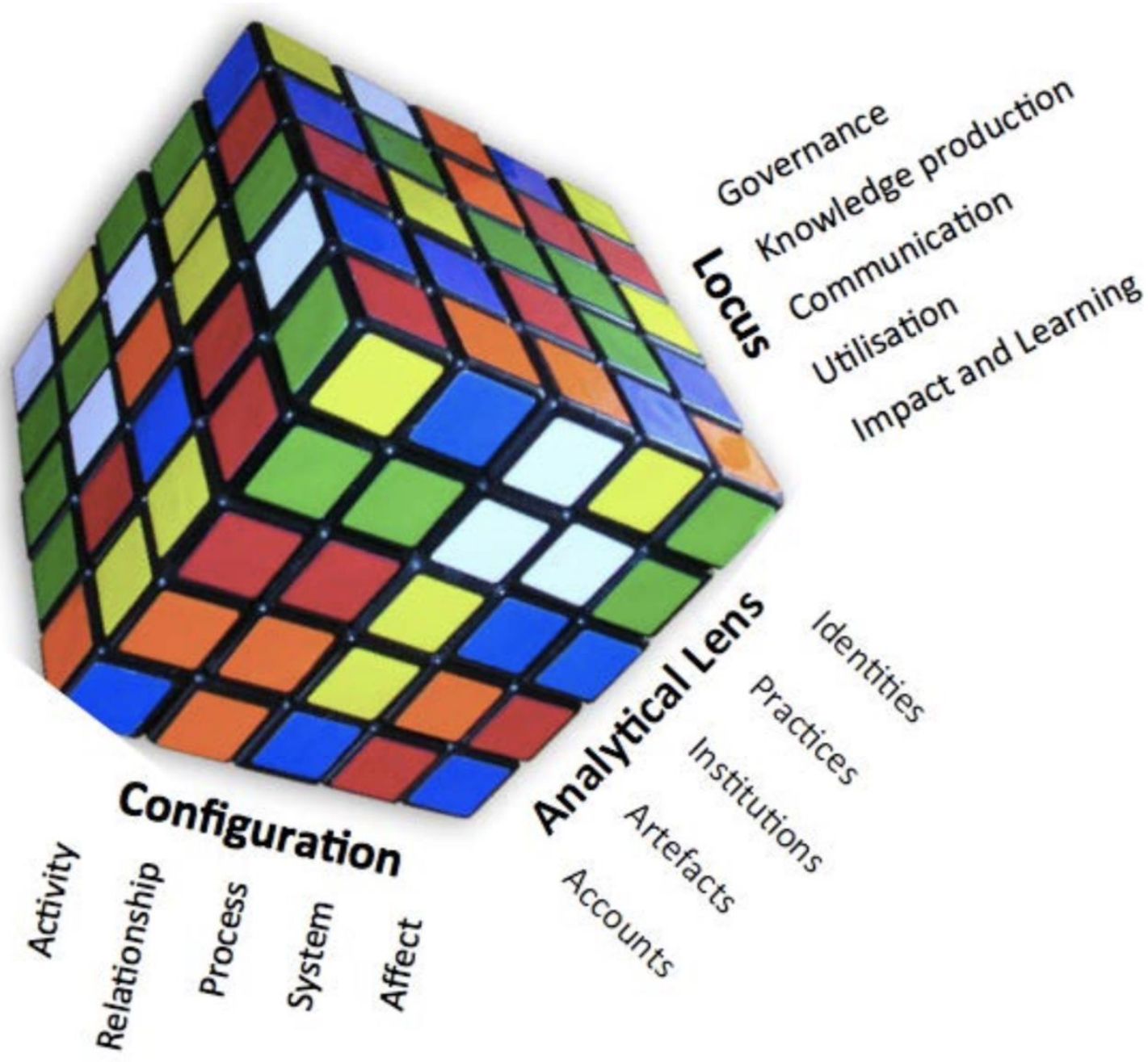

